\title{
Acculturation Strategies: The Study of Bi-Dimensional and Uni-Dimensional of Filipino Immigrants in Madrid
}

\author{
Ali Elhami \\ Universidad Autónoma de Madrid (UAM), Spain \\ E-mail: a.elhami.ali@gmail.com
}

Received: February 1, 2020 Accepted: February 25, 2020 Published: March 23, 2020

doi:10.5296/ijssr.v8i2.16428 URL: http://dx.doi.org/10.5296/ijssr.v8i2.16428

\begin{abstract}
In recent decades due to a noticeable increase in migration, there has been increasing scholarly attention given to problems immigrants are facing. It seems that the most significant challenges for immigrants are adapting to the new culture and being part of the new society. However, there are numerous factors that not only may affect the type of acculturation strategy immigrants take advantage of, but also boost adaptation or the other way round, stop them or hinder the adaptation and acculturation process. This paper aims to make a better understanding of the demographical features (age, gender, and level of education) with uni-dimensional and bi-dimensional acculturation strategies. The researcher has used an online questioner (Vancouver Index of Acculturation) for 35 participants (Filipino immigrants) in Madrid, Spain. The author hopes that this paper helps migrants especially Filipinos, who envisage emigration and accommodating in a new society with a new language and culture, to make a better decision for migration concerning gender, age, and educational level in the target country.
\end{abstract}

Keywords: Migration, Acculturation, Vancouver Index of Acculturation, Uni-dimensional and bi-dimensional acculturation, Demographic features, Filipinos 


\section{Introduction}

Migration is a courageous decision. Sometimes people have to emigrate from their own country of origin due to political, or religious problems, but other groups move to other countries by their own decision for finding a job, having education in top universities, or freedom. However, the story of migrants starts after entering to the host society. There are many problems (e.g. discrimination, language learning, cultural distance, and being accepted by the host community) immigrants face and many factors (e.g. age, gender, social class, educational level, and language knowledge) may affect those problems.

Destinations such as Canada, Australia, and the United States which are English language counties has always been among the first choices of most of the people who leave their home counties around the world, but due to long process of migration in those countries, European countries are another destination where face a steady influx of immigrants. Among European countries, Spain would be a good choice for Filipinos, thanks to two main reasons, firstly the process of migration is faster than those countries and, secondly, the process of receiving a Spanish passport is very short for Filipinos in Spain in comparison with other Asian people.

Due to a lack of knowledge of the language of European countries, adaptation to the host country will be hampered or delayed. As mentioned above, they may face numerous problems related to adaptation, language learning, finding friends, understanding the culture of the host society, etc. Owing to increasing the number of migration, and the problems immigrants face after entering to the new environment, acculturation, and the factors affecting acculturation strategies are important issues which need further research.

This study focuses on Filipino immigrants and the acculturation (uni-dimensional and bi-dimensional), due to some reasons (based on researcher's observation) such as, the number of Filipinos in Madrid, high cohesiveness, intergroup and intragroup contact, and support from Spanish government ( for most of the nationalities in Spain it takes about 10 years to receive Spanish passport, whereas for Filipinos it takes only 2 years) that decrease the perceived discrimination, it is expected that demographic features (age, gender, and level of education) do not have a significant impact on Filipino immigrants in employing uni-dimensional or bi-dimensional acculturation model.

\section{Review of Related Literature}

\subsection{Migration}

Before clarifying the notion of acculturation, first, we need to mention the reason(s) scholars (e.g., Redfield, Linton \& Herskovits, 1936; Herskovits, 1938; Linton, 1940, Berry, 1997, 1998, 2006a, 2006b) study about it. Nowadays, an increasingly large number of people leave their own countries intending to migrate. Two noted reasons commonly mentioned for migration are unemployment and low-income wages, but numerous factors may promote citizen emigration. Sam \& Berry (2006), for instance, mention war, famine and natural disasters, together with expedient access to international travel. Furthermore, countries can be classified into two types, based on Sam and Berry (2006) countries are either sender or receiver. Senders are those that people do not feel satisfied inside and try to depart for 
destinations in which can reach their goals, whereas receivers that are those where people think by living there can achieve their goals and will have or think they will have a rosy future and in brief, they believe whatever they did not have or could not have in their country of origin they will obtain in the target country. This classification can be used even within a country, some cities with higher job opportunities and more facilities can be named as receiver and others with fewer facilities and opportunities which cause their citizens to abandon their place of origin (city or village) and sweep along other main cities are called sender.

About types of migrants, Berry (2006a) put migrants in short-term or long-term categorization. Whereas, for Ward, Bochner and Furnham (2001) migrants are those whose stay lasts long and they draw a distinction between short term travelers (sojourners) and migrants. In this categorization, sojourners are those who stay for a short time, such as tourists, business travelers and, students. This group of travelers has a goal such as visiting another country and having a good time, to earn more money due to their business, or to study in a university and all of them after achieving their goals will return to their country of origin, and in another word, Bochner (2006) implies that sojourners are a group of culture travelers who travel to achieve their aim in a particular period and then go back to their country. In contrast, migrants who stay for a longer time are immigrants and refugees. It is necessary to say that among migrants, refugees do not have the same feeling as immigrants. Those who are called involuntary migrants (Ikeguchi, 2008) or forced migrants (Ager, 1999), often do not want to leave their own country. But nowadays this way (to be a refugee) is a way for those who are not able to immigrate legally or looking for a faster way to immigrate. They first choose their target country and by making a refugee case such as having a religions problem or politics problem leave their country of origin, therefore, we cannot call all of them involuntary or forced migrants. Subsequently, the marked growth of migration and trying to find out the relationship between different cultures and behaviors (Sam \& Berry, 2006) are important reasons for studying acculturation.

\subsection{Acculturation Model}

In this part, we need to consider the concept of acculturation which is a social process in which people tackle, learn, or even reject the new and unfamiliar cultural behaviors. Many scholars believe that continued contact between different cultural backgrounds causes some cultural and psychological changes to happen is known as acculturation (e.g., Berry, 2006a; Sam \& Berry, 2006; Sam, 2006; and Redfield et al., 1936). In (2002) Berry mentions changes during the acculturations process would be changing in family, individual and also the culture of people. Additionally, Redfield et al (1936) and Rothe, Tzuang, and Pumariega (2010) consider that those changes in the culture of either individuals or groups do not only happen for migrants but may also happen for dominants. Acculturation is not a unidirectional process (Berry, 2002) and it is a two-way interaction (Sam \& Berry, 2010).

In defining acculturation, almost all scholars (e.g. Berry, 2006b; Sam \& Berry, 2006; Sam, 2006; Berry, Sam \& Rogers, 2006; Redfield et al., 1936) used two main notions: "contact" and "change". They believe that acculturation is a process that occurs in continuous and 
first-hand contact that via this contact some changes will happen.

\subsection{Building Blocks}

By and large, three issues that play an influential role in the acculturation process, are contact, reciprocal influence, and change are known as the building blocks (Redfield et al., 1936; Sam, 2006). Firstly, we need to consider the notion of contact, which shapes individuals or groups. Over history, people have traveled for different reasons, hence contact between different cultures is not a new event. Bochner (2006) names intercultural contact as a daily fact in people's lives due to different reasons for traveling and also, he points out that this daily fact is for both travelers and hosts. Sam (2006) argues that contact is the preeminent phenomenon that helps the acculturation process commences. Hence, it can be said that without contact between different cultures acculturation never happens. As it was mentioned before, contact must have two characteristics for acculturation to happen. These two main characteristics are "first-hand and continued" (Sam, 2006). Secondly, reciprocal influence, which means both groups and individuals influence each other. Grounded upon, Redfield et al (1936) and Sam (2006) believe that usually, one (dominant) group influences more the other (non-dominant) group due to power differences, such as economic or military rules. It is axiomatic to believe that both contact and reciprocal influence results in changes in groups or individuals. And those changes, as a result of cultural contact, may encompass attitudes, behaviors, values, and cultural identity (Sam \& Oppedal, 2003; Sam, 2006). Sam (2006) further stresses that changes that continue for a long period are known as "adaptation". Ward (2001) and Ward et al (2001) point out that three areas in people's lives will change during the acculturation process, which is named as the ABC of acculturation. Stress, coping, and adaptation (Berry, 2006b), cultural learning (Masgoret \& Ward, 2006), and social identification orientation (Sam \& Berry, 2010).

\subsection{Adaptation}

At the outset of arrival, migrants may face grave problems: homesickness, financial struggles and, very significantly, a clash between language and culture in which they were first socialized with the language and culture of the target community. Adsera \& Pytlikova (2012) claim that "fluency in the language of the destination country plays a key role in the transfer of human capital from the source country to another country and boosts the immigrant's rate of success at the destination's labor market" (p. 1). When immigrants join a new country, however, they often suffer the absence of the vital knowledge of the language and culture of the target country and must make a very significant effort to acquire that knowledge. Factors such as the mother tongue or the number of fellow citizens (in-group) who live in the new country seem very important in the process of learning the new language and the culture of the target community. Ellis (2008) names five reasons why immigrants do not adapt to the language and culture of the target country:

1. They identify strongly with their own in-group; 2 . They see their in-group as inferior to the dominant out-group; 3. Their perception of their ethnolinguistic vitally is high; 4. They perceive in-group boundaries as hard and closed, and 5. They do not identify with other social groups and so have an inadequate group status ( $p, 333)$. 
Many factors influence the process of adapting to the new society and learning a new culture and many of them seem to be age and gender-related, as pointed out by Dion and Dion (2001), Tang and Dion (1999) and Nshom and Croucher (2018).

\subsection{Uni-Dimensional and Bi-Dimensional Acculturation}

As mentioned before, acculturation is the result of changes that happen during first-hand intercultural contact, and change and Adaptation are the results of this type of contact. Sam (2006) believes that, as adaptation may happen during or after acculturation, rejection or resistance also may happen. Accordingly, Berry (1997, 1980, and 2006) introduces two dimensions that can be selected by individuals or groups: they may want to maintain their origin culture, or they may prefer to get in contact and adapt to the larger society. Based on those two dimensions (maintenance or adaptation), three models of acculturation are introduced: the uni-dimensional model (Gordon, 1964; Arends-Toth \& Van de Vijver, 2006) in which, as a result of learning skill(s) of the host society their skill(s) of heritage culture will fade. (Arends-Toth \& Van de Vijver, 2006; Celenk \& Van de Vijver, 2011). For instance, one will gradually lose their ability to etiquette while learns etiquette of the host country.

The second model is the bi-dimensional, one in which learning the skills of host society does not influence heritage skills (La Frombois, Coleman \& Gerton, 1993; Sayegh \& Larsy, 1993; Berry, 1997; Arends-Toth \& Van de Vijver, 2006; Celenk \& Van de Vijver, 2011 ) and individuals experience better adaption process (Navas et al., 2005). In one study on uni-dimensional and bi-dimensional acculturation, Ryder et al (2000) find out that in the bi-dimensional model both cultures (heritage and the mainstream) are statistically independent.

Finally, the last model is called Fusion (Coleman, 1995; Arends-Toth \& Van de Vijver, 2006), or making an integrated culture, which ends up in a mixture of both cultures. With this model, it can be proved that acculturation can not only be a choice between cultures, but also a mixture of two different cultures (Arends-Toth \& Van de Vijver, 2006).

\section{Method}

\subsection{Participants}

The participants in this study were 35 Filipino immigrants in Madrid, Spain through snowball sampling. Among all participants (21) $60 \%$ of them were females and (14) $40 \%$ were males. (3) $8.6 \%$ of the participants were 10 to 20 years old, (7) $20 \%$ were between 21 to 30 years old, Majority of the participants (17) $48.6 \%$ were between 31 to 40 years old, (5) $14.3 \%$ were between 41 to 50 and the rest (3) $8.6 \%$ were between 51 to 60 years old. The sample includes only the first-generation immigrants who have been living in Spain for at least 3 months. To my mind under 3 months of arrival (for Filipino immigrants) immigrants have a very limited range of Spanish words and grammatical structure in use, and the study requires that they can be able to know at least a little Spanish. And also in 3 months immigrants have enough time to find a settlement, the way to adapt themselves, learn a little about Spanish culture, and many other things that play important roles in this study. 


\section{Macrothink

\subsection{Procedure}

In this quantitative study, data were collected through a questioner. Before giving the questioner to the participants they were informed that their participation is completely voluntary and the responses will be anonymous, therefore, they will not be identified. The questionnaire consist of two parts, demographic features (name, age range, gender, and level of education) and Vancouver index of acculturation (Ryder, Alden, \& Paulhus, 2000) which "is a self-reported bi-dimensional instrument" (Testa, Doucerain, Miglietta, Jurcik, Ryder, \& Gattino, 2019, p. 60) and contains 20 questions related to Spanish culture and their culture of origin, including marital preference, social activity, friendship, etc. All 20 questions in this part are 5-point scale rating, range from (1) completely disagree to (5) completely agree

Demographic features and acculturation strategies are two focal points in this study to find out the relationship between personal factors and the type of acculturation strategy that Filipino immigrants in Spain take advantage of.

\section{Results}

\subsection{Result 1 (Gender and Uni-dimensional / Bi-dimensional acculturation)}

Fisher's Exact Probability Test was used in order to response to the three research questions of the current study. In fact, both Pearson's chi-square and Likelihood Ratio chi-square statistics perform well when the contingency tables have reasonable number of observations in each cell. When samples are small (as in this research), i.e. the distributions are not well approximated by the chi-squared distribution; thus the $\mathbf{p}$ values for the hypothesis tests are not to be trusted. In such situation we can perform inference using exact distributions (or estimates of exact distributions). Moreover, all $\mathbf{p}$ values below .10 were also reported due to the fact that the number of the participants of the study is not very large.

As set forth in Table 1, Fisher's Exact Probability Test indicated that gender was not a statistically significant (Fisher's Exact Sig. $(p)>.10)$ ) factor for Filipino immigrants to Spanish tendency towards their original culture in terms of all 10 items of the questionnaire that were related to heritage (Filipino Origin) dimension of acculturation. 
Table 1. Fisher's Exact Test for Heritage (Filipino Origin) Dimension of Acculturation by Gender

\begin{tabular}{|c|c|c|}
\hline Item & $\begin{array}{l}\text { Fisher's Exact } \\
\text { Test Value }\end{array}$ & $\begin{array}{l}\text { Exact Sig. } \\
\text { (2-sided) }\end{array}$ \\
\hline 1. I often participate in my heritage cultural traditions. & 3.491 & .496 \\
\hline 3. I would be willing to marry a person from my heritage culture. & 2.463 & .509 \\
\hline $\begin{array}{l}\text { 5. I enjoy social activities with people from the same heritage culture as } \\
\text { myself. }\end{array}$ & 1.249 & .897 \\
\hline $\begin{array}{l}\text { 7. I am comfortable interacting with people of the same heritage culture as } \\
\text { myself. }\end{array}$ & 1.285 & .884 \\
\hline 9. I enjoy entertainment (e.g. movies, music) from my heritage culture. & 3.910 & .274 \\
\hline 11. I often behave in ways that are typical of my heritage culture. & 1.237 & 1.000 \\
\hline $\begin{array}{l}\text { 13. It is important for me to maintain or develop the practices of my } \\
\text { heritage culture. }\end{array}$ & 1.624 & .716 \\
\hline 15. I believe in the values of my heritage culture. & 2.027 & .415 \\
\hline 17. I enjoy the jokes and humor of my heritage culture. & 3.966 & .230 \\
\hline 19. I am interested in having friends from my heritage culture. & .956 & .792 \\
\hline
\end{tabular}

Similarly, according to the results show in Table 2, Fisher's Exact Probability Test revealed that gender was not a statistically significant (Fisher's Exact Sig. $(p)>.10)$ ) factor for Filipino immigrants to Spanish tendency towards their Spanish target culture concerning most of the items of the questionnaire that were related to mainstream (Spanish target) dimension of acculturation except for Item 8) I am comfortable interacting with typical Spanish people. (Fisher's Exact Sig. $=.089, p<.10$ ) and Item 10) I enjoy Spanish entertainment (e.g. movies, music) (Fisher's Exact Sig. $=.098, p<.10$ ), in which gender was a statistically significant factor.

In fact, regarding Item $8,85.70 \%$ of the male participants either agreed or strongly agreed with the statement that they are comfortable interacting with typical Spanish people while just $42.80 \%$ of female respondents either agreed or strongly agreed with this.

Likewise, more percentage of the male responded (78.50\%) in comparison with the females $(33.30 \%)$ either agreed or strongly agreed with the fact that they enjoy Spanish entertainment (e.g. movies, music) (Item 10). 
Table 2. Fisher's Exact Test for Mainstream (Spanish Target) Dimension of Acculturation by Gender

\begin{tabular}{lll}
\hline Item & $\begin{array}{l}\text { Fisher's Exact } \\
\text { Test Value }\end{array}$ & $\begin{array}{l}\text { Exact Sig. } \\
\text { (2-sided) }\end{array}$ \\
\hline 2. I often participate in mainstream Spanish cultural traditions. & 4.747 & .327 \\
4. I would be willing to marry a Spanish person. & 3.496 & .537 \\
6. I enjoy social activities with typical Spanish people. & 3.244 & .565 \\
8. I am comfortable interacting with typical Spanish people. & 6.820 & .089 \\
10. I enjoy Spanish entertainment (e.g. movies, music). & 7.135 & .098 \\
12. I often behave in ways that are typically Spanish. & 4.712 & .316 \\
14. It is important for me to maintain or develop Spanish cultural practices. & 4.938 & .300 \\
16. I believe in mainstream Spanish values. & 3.779 & .476 \\
18. I enjoy Spanish jokes and humor. & 4.894 & .286 \\
20. I am interested in having Spanish friends. & 2.580 & .538 \\
\hline
\end{tabular}

\subsection{Result 2 (Age and Uni-dimensional / Bi-dimensional acculturation)}

Fisher's Exact Probability Test results, as appeared in Table 3, showed that age level was not a statistically significant (Fisher's Exact Sig. $(p)>.10)$ ) factor for Filipino immigrants to Spanish tendency towards their original culture in terms of all 10 items of the questionnaire that were related to heritage (Filipino Origin) dimension of acculturation.

Table 3. Fisher's Exact Test for Heritage (Filipino Origin) Dimension of Acculturation by Age Level

\begin{tabular}{lll}
\hline Item & $\begin{array}{l}\text { Fisher's Exact } \\
\text { Test Value }\end{array}$ & $\begin{array}{l}\text { Exact Sig. } \\
\text { (2-sided) }\end{array}$ \\
\hline $\begin{array}{l}\text { 1. I often participate in my heritage cultural traditions. } \\
\text { 3. I would be willing to marry a person from my heritage culture. }\end{array}$ & 4.007 & .934 \\
$\begin{array}{l}\text { 5. I enjoy social activities with people from the same heritage culture as } \\
\text { myself. }\end{array}$ & 3.919 & .421 \\
7. I am comfortable interacting with people of the same heritage culture as & 5.204 & .840 \\
myself. & & .569 \\
$\begin{array}{l}\text { 9. I enjoy entertainment (e.g. movies, music) from my heritage culture. } \\
\text { 11. I often behave in ways that are typical of my heritage culture. }\end{array}$ & 2.672 & .915 \\
$\begin{array}{l}\text { 13. It is important for me to maintain or develop the practices of my } \\
\text { heritage culture. }\end{array}$ & 4.684 & .570 \\
$\begin{array}{l}\text { 15. I believe in the values of my heritage culture. } \\
\text { 17. I enjoy the jokes and humor of my heritage culture. }\end{array}$ & .621 \\
19. I am interested in having friends from my heritage culture. & 3.904 & .415 \\
\hline
\end{tabular}


Furthermore, according to the results represented in Table 4, Fisher's Exact Probability Test showed that age level was not a statistically significant (Fisher's Exact Sig. $(p)>.10)$ ) factor for Filipino immigrants to Spanish tendency towards their Spanish target culture regarding majority ( 7 out of 10) of items of the questionnaire that addressed mainstream (Spanish target) dimension of acculturation, except for Item 6) I enjoy social activities with typical Spanish people (Fisher's Exact Sig. $=.008, p<.10$ ), Item 12) I often behave in ways that are typically Spanish (Fisher's Exact Sig. $=.094, p<.10$ ) and Item 18) I enjoy Spanish jokes and humor. (Fisher's Exact Sig. $=.082, p<.10$ ), in which age was a statistically significant factor.

Actually, regarding Item $6,85.70 \%$ of the male participants either agreed or strongly agreed with the statement that they are comfortable interacting with typical Spanish people while just $42.80 \%$ of female respondents either agreed or strongly agreed with this. Likewise, more percentage of the male responded $(78.50 \%)$ in comparison with the females $(33.30 \%)$ either agreed or strongly agreed with the fact that they enjoy Spanish entertainment (e.g. movies, music) (Item 10).

Specifically, concerning Item 6, the whole respondents $(100.00 \%)$ with the age of more-than-40 either agreed or strongly agreed with the fact that they enjoy social activities with typical Spanish people, followed by the participants with age of less-than-30 (60.00\%), and then the ones with age range of 31-40 (23.50\%).

Regarding Item 12, the highest percentage for either agreement or strongly agreement gained was for the age range of less-than-30 (60.00\%), followed by the age range of 31-40 (29\%), and finally the age range of more-than-40 (25.00\%).

Related to Item 18 , the results revealed that the majority (70.00\%) of the respondents with the age range of less-than-30 either agree or strongly agreed with the statement 'I enjoy Spanish jokes and humor', followed by the age range of more-than-40 (37.50\%), and finally the age range of $31-40(11.76 \%)$.

Table 4. Fisher's Exact Test for Mainstream (Spanish Target) Dimension of Acculturation by Age Level

\begin{tabular}{lll}
\hline Item & $\begin{array}{l}\text { Fisher's Exact } \\
\text { Test Value }\end{array}$ & $\begin{array}{l}\text { Exact Sig. } \\
\text { (2-sided) }\end{array}$ \\
\hline 2. I often participate in mainstream Spanish cultural traditions. & 6.370 & .654 \\
4. I would be willing to marry a Spanish person. & 4.789 & .860 \\
6. I enjoy social activities with typical Spanish people. & 16.456 & .008 \\
8. I am comfortable interacting with typical Spanish people. & 11.081 & .125 \\
10. I enjoy Spanish entertainment (e.g. movies, music). & 6.942 & .547 \\
12. I often behave in ways that are typically Spanish. & 11.697 & .094 \\
14. It is important for me to maintain or develop Spanish cultural practices. & 10.526 & .154 \\
16. I believe in mainstream Spanish values. & 4.128 & .952 \\
18. I enjoy Spanish jokes and humor. & 12.019 & .082 \\
20. I am interested in having Spanish friends. & 3.234 & .843 \\
\hline
\end{tabular}




\subsection{Result 3 (Level of education and Uni-dimensional / Bi-dimensional acculturation)}

As seen in Table 5, Fisher's Exact Probability Test discovered that level of education was not a statistically significant (Fisher's Exact Sig. $(p)>.10)$ ) factor for Filipino immigrants to Spanish tendency towards their original culture in terms of the majority ( 8 out of 10) of items of the questionnaire that were related to heritage (Filipino Origin) dimension of acculturation, except for Item 5) I enjoy social activities with typical Spanish people (Fisher's Exact Sig. $=.02, p<.10)$ and Item 7) I am comfortable interacting with people of the same heritage culture as myself (Fisher's Exact Sig. $=.04, p<.10$ ).

In view of Item 5, the highest percentage for either agreement or strongly agreement gained for the idea that they enjoy social activities with people from the same heritage culture as themselves, was for the Bachelor Degree (92.31\%), followed by Diploma Degree $(75.00 \%)$, and finally Associate Degree (66.67\%).

Pertinent to Item 7 , the results showed that more number $(81.25 \%)$ of the respondents with Diploma Degree either agreed or strongly agreed with the opinion that they are comfortable interacting with people of the same heritage culture as themselves, followed by Bachelor Degree (76.92\%), and finally Associate Degree (66.67\%).

Table 5. Fisher's Exact Test for Heritage (Filipino Origin) Dimension of Acculturation by Education Level

\begin{tabular}{lll}
\hline Item & $\begin{array}{l}\text { Fisher's Exact } \\
\text { Test Value }\end{array}$ & $\begin{array}{l}\text { Exact Sig. } \\
\text { (2-sided) }\end{array}$ \\
\hline $\begin{array}{l}\text { 1. I often participate in my heritage cultural traditions. } \\
\text { 3. I would be willing to marry a person from my heritage culture. }\end{array}$ & 9.919 & .195 \\
5. I enjoy social activities with people from the same heritage culture as & 12.274 & .994 \\
myself. & & .020 \\
7. I am comfortable interacting with people of the same heritage culture as & 10.948 & .045 \\
myself. & & 7.476 \\
$\begin{array}{l}\text { 9. I enjoy entertainment (e.g. movies, music) from my heritage culture. } \\
\text { 11. I often behave in ways that are typical of my heritage culture. }\end{array}$ & 10.290 & .241 \\
$\begin{array}{l}\text { 13. It is important for me to maintain or develop the practices of my } \\
\text { heritage culture. }\end{array}$ & 5.610 & .163 \\
15. I believe in the values of my heritage culture. & & .473 \\
17. I enjoy the jokes and humor of my heritage culture. & 5.722 & .170 \\
19. I am interested in having friends from my heritage culture. & 5.394 & .499 \\
\hline
\end{tabular}

Likewise, according to the results summarized in Table 6, Fisher's Exact Probability Test uncovered that level of education was not a statistically significant (Fisher's Exact Sig. $(p)>.10)$ ) factor for Filipino immigrants to Spanish tendency towards their Spanish target culture in a large number of items ( 7 out of 10) of items of the questionnaire that coped with 
mainstream (Spanish target) dimension of acculturation, except for Item 4) I would be willing to marry a Spanish person (Fisher's Exact Sig. $=.089, p<.10$ ), Item 10) I enjoy Spanish entertainment (e.g. movies, music). (Fisher's Exact Sig. $=.074, p<.10$ ), and Item 16) I believe in mainstream Spanish values (Fisher's Exact Sig. $=.04, p<.10$ ), in which participants' level of education was a statistically significant factor.

In terms of Item 4, more number (46.15\%) of respondents with Diploma Degree either agreed or strongly agreed with the idea that they would be willing to marry a Spanish person in comparison with Bachelor Degree (36.36), and the Associate Degree (0.00\%).

In view of Item 10, analyzing the results uncovered that the highest percentage for either agreement or strongly agreement gained for the idea that they enjoy Spanish entertainment (e.g. movies, music), was for the Bachelor Degree (76.92\%), followed by Diploma Degree (37.50\%), and finally Associate Degree (33.33\%).

Pertinent to Item 16 , the results discovered that more number $(43.75 \%)$ of the respondents with Diploma Degree either agreed or strongly agreed with the notion that they believe in mainstream Spanish values, followed by Bachelor Degree (38.46\%), and finally Associate Degree (33.33\%).

Table 6. Fisher's Exact Test for Mainstream (Spanish Target) Dimension of Acculturation by Education Level

\begin{tabular}{llc}
\hline Item & $\begin{array}{l}\text { Fisher's Exact } \\
\text { Test Value }\end{array}$ & $\begin{array}{c}\text { Exact Sig. } \\
\text { (2-sided) }\end{array}$ \\
\hline 2. I often participate in mainstream Spanish cultural traditions. & 5.090 & .806 \\
4. I would be willing to marry a Spanish person. & 11.819 & .089 \\
6. I enjoy social activities with typical Spanish people. & 6.160 & .679 \\
8. I am comfortable interacting with typical Spanish people. & 7.433 & .531 \\
10. I enjoy Spanish entertainment (e.g. movies, music). & 12.464 & .074 \\
12. I often behave in ways that are typically Spanish. & 5.138 & .828 \\
14. It is important for me to maintain or develop Spanish cultural practices. & 7.186 & .503 \\
16. I believe in mainstream Spanish values. & 13.315 & .043 \\
18. I enjoy Spanish jokes and humor. & 6.789 & .592 \\
20. I am interested in having Spanish friends. & 3.197 & .878 \\
\hline
\end{tabular}

liability for Heritage Section

\begin{tabular}{ll}
\hline Reliability Statistics & \\
\hline Cronbach's Alpha & N of Items \\
.886 & 10 \\
\hline
\end{tabular}




\section{Macrothink

Reliability for Mainstream Section

\begin{tabular}{ll}
\hline Reliability Statistics & \\
\hline Cronbach's Alpha & N of Items \\
.902 & 10 \\
\hline
\end{tabular}

Reliability for Total Questionnaire

\begin{tabular}{ll}
\hline Reliability Statistics & \\
\hline Cronbach's Alpha & N of Items \\
.909 & 20 \\
\hline
\end{tabular}

\section{Discussion and Conclusion}

The present study was conducted to ascertain the effect of demographical features (age range, gender, and educational level) on uni-dimensional and bi-dimensional acculturation models among Filipino immigrants in Madrid, Spain. The study was divided into three parts. The first part was done to find out if age has a significant impact on Filipino immigrants to employ uni-dimensional and di-dimensional acculturation. Which the result revealed that age does not affect nor maintaining the heritage culture neither adapting to the new culture (culture of the host community). Also, the second part which was measuring the effect of gender and uni-dimensional and bi-dimensional acculturation showed that gender dosed not have any effect on maintaining the heritage culture or adapting and integrating to the host culture as well. Likewise, the level of education has the same effect as age and gender in this study.

Some limitations of this study are notable, which the most significant one was the number of the participants, unlike Testa et al, 2019 who omitted two questions related to marriage, "I would be willing to marry a Spanish person" and "I would be willing to marry a person from my heritage culture", the researcher in this study tried to collect the data through single Filipinos who have been living in Madrid, therefore, those two questions related to marriage were not omitted. Also due to a small number of participants and to be able to have better category parameters, the 9 point scale from completely agree to disagree, has reduced to 5 point scale.

In conclusion, the results in this study support the findings of Gattino, Miglietta, Rizzo, Testa (2016) and Rubenfeld et al (2012) about the bi-dimensionality of Vancouver Index of Acculturation, and aslo, showed that demographic features (age, gender, and level of education) do not have a significant effect on maintenance or adaptation among Filipino immigrants in Madrid, Spain.

Also, further studies related to acculturation and adaptation to investigate VIA are needed in Spain which is a diverse country with different nationalities from different countries such as China, Iran, and Morocco that have larger cultural distance in comparison with those from other European countries. 


\section{Macrothink}

International Journal of Social Science Research

ISSN 2327-5510

2020, Vol. 8, No. 2

\section{References}

Adsera, A., \& Pytliková, M. (2015). Role of language in shaping international migration. The economic Journal, 125(586), 49-81. https://doi.org/10.1111/ecoj.12231

Ager, A. (Ed.) (1999). Refugees: Perspectives on the experience of forced migration. London: Cassell.

Arends-T'oth, J., \& van de Vijver, F. J. R. (2006). Assessment and psychological acculturation. In D. Sam \& J. W. Berry (Eds.), Handbook of acculturation psychology (pp. 142-165). Cambridge University Press. https://doi.org/10.1017/CBO9780511489891.013

Berry, J. W. (1980). Acculturation as varieties of adaptation. In A. Padilla (Ed.), Acculturation: Theory, models and some new findings (pp. 9-25). Boulder, CO: Westview.

Berry, J. W. (1997). Immigration, acculturation, and adaptation. Applied Psychology: An International Review, 46(1), 5-68. https://doi.org/10.1111/j.1464-0597.1997.tb01087.x

Berry, J. W. (2002). Acculturation: Living successfully in two cultures. International Journal of Intercultural Relations, 29, 697-712. https://doi.org/10.1016/j.ijintrel.2005.07.013

Berry, J. W. (2006a). Stress perspective on acculturation. In D. Sam \& J. W. Berry (Eds.), Handbook of acculturation psychology (pp.43-57). Cambridge University Press. https://doi.org/10.1017/CBO9780511489891.007

Berry, J. W. (2006b). Context of acculturation. In D. Sam \& J. W. Berry (Eds.), Handbook of acculturation psychology (pp.27-42). Cambridge University Press. https://doi.org/10.1017/CBO9780511489891.006

Berry, J. W., Sam, D., \& Rogers, A. (2006). Conclusions. In D. Sam \& J. W. Berry (Eds.), Handbook of acculturation psychology (pp.525-541). Cambridge University Press. https://doi.org/10.1017/CBO9780511489891.037

Bochner, S. (2006) Sojourners. In D. Sam \& J. W. Berry (Eds.), Handbook of acculturation psychology (pp.181-197). Cambridge University Press. https://doi.org/10.1017/CBO9780511489891.016

Celenk, O., \& van de Vijver, F. J. (2011). Assessment of acculturation: Issues and overview of measures. Online Readings in Psychology and Culture, 8, 1-10. https://doi.org/10.9707/2307-0919.1105

Coleman, H. L. K. (1995). Strategies for coping with cultural diversity. Counseling Psychologist, 23, 722-740. https://doi.org/10.1177/0011000095234011

Dion, K. K., \& Dion, K. L. (2001). Gender and cultural adaptation in immigrant families. The Journal of Social Issues, 57(3), 511-521. https://doi.org/10.1111/0022-4537.00226

Ellis, R. (2008). The study of second language acquisition (2nd ed.). Oxford university press.

Gattino, S., Miglietta, A., Rizzo, M., \& Testa, S. (2016). Muslim Accultuation in a Catholic Country: Its association with religious identity, beliefs, and practices. Journal of 
Cross-Cultural Psychology, 47(9), 1194-1200. https://doi.org/10.1177/0022022116661244

Gordon, M. (1964). Assimilation in American life. New York: Oxford University Press.

Herskovits, M. J. (1938). Acculturation: The study of culture contact. New York: Augustin.

Ikeguchi, C. (2008). Cultural learning and adaptation: A closer look at the realities. Journal of Intercultural Communication Studies, XVII(1).

La Fromboise, T., Coleman, H. L. K., \& Gerton, J. (1993). Psychological impact of biculturalism: Evidence and theory. Psychological Bulletin, 114(3), 395-412. https://doi.org/10.1037/0033-2909.114.3.395

Linton, R. (1940). Acculturation in seven American Indian tribes. New York: Appleton-Century. https://doi.org/10.2307/1896110

Masgoret, A. M., \& Ward, C. (2006). The cultural learning approach to acculturation. In D. L. Sam \& J. W. Berry (Eds.), Cambridge Handbook of Acculturation Psychology (pp. 58-77). Cambridge United Kingdom: Cambridge University Press. https://doi.org/10.1017/CBO9780511489891.008

Navas, M., García, M. C., Sánchez, J., Rojas, A. J., Pumares, P., \& Fernández, J. S. (2005). Relative Acculturation Extended Model (RAEM): New contributions with regard to the study of acculturation. International Journal of Intercultural Relations, 29, 21-37. https://doi.org/10.1016/j.ijintrel.2005.04.001

Nshom, E., \& Croucher, S. M. (2018). Acculturation preferences towards immigrants: Age and gender differences among Finnish adolescents. International Journal of Intercultural Relations, 65, 51-60. https://doi.org/10.1016/j.ijintrel.2018.04.005

Redfield, R., Linton, R., \& Heskovits, M. J. (1936). Memorandum for the study of acculturation. American Anthropologist, $\quad 38, \quad$ 149-152. https://doi.org/10.1525/aa.1936.38.1.02a00330

Rubenfeld, S., Sinclair, L., \& Clement, R. (2012). Second language learning and acculturation: The role of motivation and goal content congruence. Canadian Journal of Applied Linguistics, 10(3), 309-323.

Ryder, A. G., Alden, L. E., \& Paulhus, D. L. (2000). Is acculturation unidimensional or bidimensional? A head-to-head comparison in the prediction of personality, selfidentity, and adjustment. Journal of Personality and Social Psychology, 79, 49-65. https://doi.org/10.1037//0022-3514.79.1.49

Sam, D. (2006). Acculturation: conceptual and methods. In D. Sam \& J. W. Berry (Eds.), Handbook of acculturation psychology (pp. 11-26). Cambridge University Press. https://doi.org/10.1017/CBO9780511489891

Sam, D. L., \& Berry, J. W. (2006). The Cambridge handbook of Acculturation Psychology. Cambridge University Press. https://doi.org/10.1017/CBO9780511489891 


\section{Macrothink}

International Journal of Social Science Research

ISSN 2327-5510 2020, Vol. 8, No. 2

Sam, D. L., \& Berry, J. W. (2010). Acculturation: When Individuals and Groups of Different Cultural Background Meet. Perspective on Psychological Science, 5(4), 472-481. https://doi.org/10.1177/1745691610373075

Sam, D. L., \& Oppedal, B. (2003). Acculturation as a Developmental Pathway. Online Readings in Psychology and Culture, 8(1). https://doi.org/10.9707/2307-0919.1072

Sayegh, L., \& Lasry, J. C. (1993). Immigrants' adaptation in Canada: Assimilation, acculturation, and orthogonal cultural identification. Canadian Psychology/ Psychologie Canadienne, 34(1), 98-109. https://doi.org/10.1037/h0078777

Tang, T. N., \& Dion, K. L. (1999). Gender and Acculturation in Relation to Traditionalism: Perceptions of Self and Parents among Chinese Students. Sex Roles, 41, 17-29. https://doi.org/10.1023/A:1018881523745

Testa, S., Doucerain, M. M., Miglietta, A., Jurcik, T., Ryder, G. A., Gattino, S. (2019). The Vancouver Index of Acculturation (VIA): New evidence on dimensionality and measurement invariance across two cultural settings. International Journal of Intercultural Relations, 34, 60-71. https://doi.org/10.1016/j.ijintrel.2019.04.001

Ward, C. (2001). The A, B, Cs of acculturation. In D. Masumoto (Ed.), The handbook of culture and psychology (pp. 411-445). New York, NY: Oxford University Press.

Ward, C., Bochner, S., \& Furnham, A. (2001). The psychology of culture shock. Philadelphia: Routledge.

\section{Copyright Disclaimer}

Copyright for this article is retained by the author(s), with first publication rights granted to the journal.

This is an open-access article distributed under the terms and conditions of the Creative Commons Attribution license (http://creativecommons.org/licenses/by/3.0/). 